\title{
Prevalence of enteropathogens in normal feces from healthy children at an infant day care in Brazil
}

\author{
Cláudia de Moura, Maria Clara Duarte Fregolente, Isabel Julien Martini, Daniela Ferreira \\ Domingos, Erivaldo José da Silva, Mirtis Maria Giaciani Ferraz, Maria Silvia Viccari Gatti, \\ Domingos da Silva Leite
}

Department of Genetics, Evolution and Bioagents, Institute of Biology, State University of Campinas, Campinas, $S P$, Brazil

\begin{abstract}
Introduction: The diarrhea associated with gastroenteritis is a major cause of morbidity and mortality worldwide, affecting mainly infants. The characterization of both viral and bacterial agents associated with gastroenteritis can establish policies for surveillance, prevention and treatment of infections. Group A rotaviruses are the major infectious agent associated with dehydration in children, followed by pathotypes of Escherichia coli. There are three main types of clinical infections caused by E. coli strains that have acquired virulence genes: (i) enteric and diarrheal diseases, (ii) urinary tract infections, and (iii) sepsis and meningitis.

Methodology: In this study, the objective was to identify the presence of rotavirus and diarrhogenic E. coli in the feces of children 4 to 14 months of age who displayed no gastroenteritis symptoms and stayed all day in a day-care center. We analyzed 188 samples using PAGE and PCR to identify rotaviruses and E. coli virulence genes, respectively.

Results: Thirty-six samples (19.1\%) were positive for at least one pathotype of E. coli. Nineteen were identified to be of the EPEC group and fifteen of the EAEC group. Rotaviruses were not identified.

Conclusions: As EPEC and EAEC are potential pathogens for children less than one year of age or immunocompromised individuals, our results show the importance of appropriate monitoring by public health agencies. In the situation that we have studied, children can be considered asymptomatic carriers of these pathogens and can transmit them to other susceptible children.
\end{abstract}

Key words: enteropathogen; children; day-care center; Escherichia coli; rotavirus

$J$ Infect Dev Ctries 2012; 6(2):176-180.

(Received 24 March 2011 - Accepted 14 August 2011)

Copyright (c) 2012 Moura et al. This is an open-access article distributed under the Creative Commons Attribution License, which permits unrestricted use, distribution, and reproduction in any medium, provided the original work is properly cited

\section{Introduction}

Diarrhea is the major cause of morbidity and mortality worldwide, mainly affecting children less than five years of age. In the world, the probability of transmission of infectious agents among children in a nursery school ranges from $50 \%$ to $71 \%$ during outbreaks. Moreover, these rates are lower $(15 \%$ on average) in children not exposed to that environment [1]. In developing countries, viruses, bacteria, and parasites are associated with outbreaks of gastroenteritis in day-care centers. Among them, rotavirus and diarrheogenic Escherichia coli (DEC) are considered to be the most common enteropathogenic organisms [2].

In general, rotaviruses are responsible for $20 \%$ to $60 \%$ of cases of hospitalization due to diarrhea [1]. The infection frequently occurs in the winter in temperate climates, but in tropical settings and in developing countries a defined seasonality has not been observed [3]. In Brazil, rotavirus cases are mainly observed in settings with high human contact, such as schools, day-care centers, hospitals and big families [4]. Therefore in 2006, immunization of infants with two doses of RV1 vaccine was initiated [5]. Since then, cases of rotavirus disease in children have decreased significantly while other enteropathogens are incriminated in diarrheic outbreaks in children. Studies in the city of São Paulo, Brazil, showed predominance of diarrheic Escherichia coli, mainly enteropathogenic E. coli (EPEC), in $40 \%$ of cases of acute diarrhoea [6].

Based on symptoms and specific virulence factors, diarrheic E. coli are classified into six categories: enteropathogenic E. coli (EPEC), enteroaggregative $E$. coli (EAEC), shigatoxigenic $E$. coli (STEC), enterohemorrhagic E. coli (EHEC), enterotoxigenic $E$. coli (ETEC) and enteroinvasive $E$. coli (EIEC) [7]. 
EPEC are associated with infantile diarrhea. The principal protein (intimin) involved in this phenotype is codified by the eae gene. Typical strains of EPEC harbor the eae gene and the EAF plasmid (EPEC adherence factor plasmid). Atypical strains have eae gene but lack the EAF-plasmid, while other atypical EPEC contain parts of the plasmid but do not express bundle-forming pili for adherence [8]. STEC are the $E$. coli strains that only produce shiga toxin (STx) whereas EHEC produce Stx and have the capability to induce $\mathrm{A} / \mathrm{E}$ lesions [7].

ETEC has been associated with watery diarrhea in children and traveller's diarrhea. This group is distinguished by the ability to produce enterotoxins, heat stable enterotoxins (STs), codified by estI gene and/or heat labile toxins (LTs), expressed by eltI gene [7].

EAEC are usually distinguished by an aggregative adherence pattern on HEp-2 cultured cells. Certain strains carry a high-molecular-weight plasmid (pAA) associated with aggregative adherence [9] on which a number of virulence genes are located, including an antiaggregation protein transporter gene (aat; previously referred to as CVD432) [10] and an enteroaggregative heat stable toxin (EAST) gene (ast A). EIEC group has the capacity to invade tissue, causing dysentery [7].

EIEC are classified biochemically as E. coli but share many properties, including virulence mechanisms, with Shigella. The organisms possess a large invasion plasmid, which encodes the Mxi-Spa type III secretion system and invasion plasmid antigen (Ipa) effectors, conferring upon these bacteria the ability to invade eukaryotic cells. The ipaH gene can be used as molecular marker for PCR [8].

In spite of the availability of modern, rapid, and easy-to-use diagnostic techniques, such as virulence gene-specific PCR, screening for DEC categories is not routinely performed in Brazilian clinical laboratories. Thus the objective of this study was to screen rotavirus-immunized children for the presence of different pathotypes of E. coli. We also aimed to verify whether children could have asymptomatic infections with diarrheogenic pathogens and function as carriers in the population.

\section{Methodology}

Study population

From May (autumn) to August (winter) of 2006, a total of 94 children who stay all day in an infant day-care center in Unicamp, Brazil, were screened for the presence of viral and bacterial enteric agents and were monitored throughout the period for signs of diarrhea. The staff feed the children meals that are prepared at the day care 3 times per day. The children could also be breast-fed by their mothers twice per day. All children received rotavirus vaccine (Rotarix, Glaxo Smith Kline Biologicals, Middlesex, United Kingdom) administered by the Brazilian public health system.

Sampling

Two stool samples were collected for each child and a total of 188 set samples of feces were analyzed. All children were monitored throughout the period for signs of diarrhea. This study was approved by the Ethics Committee for Research on Humans of the State University of Campinas (UNICAMP), with ID number 483/2004.

\section{Identification of rotavirus by $P A G E$}

The samples were screened by sodium dodecyl sulfate polyacrylamide gel electrophoresis (SDSPAGE) (7.5\%) after phenol-chloroform extraction of viral double-stranded RNA. Polyacrylamide gels were silver stained [11].

Bacterial identification and detection of virulence factors of diarrheic E. coli

Fecal samples were plated onto MacConkey agar (Difco) medium. A loopful of bacterial growth or ten E. coli-like colonies taken from the first streaking area of the fecal culture plates was suspended in 0.5 $\mathrm{mL}$ of sterile water and boiled for five minutes to release the DNA which was subsequently subjected to PCR. If no positive colony was found among the first ten, at least 40 more colonies were tested. All the $E$. coli isolates were subsequently characterized using biochemical identification $[12,13]$.

Pathotypes of E. coli were detected by PCR using specific primers for the following seven $E$. coli virulence genes: stx $1 /$ stx 2 in STEC and EHEC; eltI and estI in ETEC; eae in EPEC and EHEC; ipaH in EIEC and $p C V D 432$ plasmid in EAEC (Table 1).

The PCR reactions were performed using $1 \mathrm{X}$ PCR Buffer; $2 \mathrm{mM} \mathrm{MgCl} 2 ; 0.2 \mathrm{mM}$ dNTP; $1.5 \mathrm{U}$ Taq DNA polymerase (Fermentas, Burlington/Canada); 7 $\mu \mathrm{L}$ DNA template; and $60 \mathrm{ng}$ of each primer. The products were analyzed by electrophoresis on a $1.5 \%$ agarose gel. The gel was stained with ethidium bromide and imaged under UV transillumination (LKB MacroVue Pharmacia, GE Life Science, Germany). 
Table 1. Primers used on PCR methods for diarrheogenic Escherichia coli detection

\begin{tabular}{|c|c|c|c|}
\hline Gene & $\begin{array}{r}\text { Primer }\left(5^{\prime}-3^{\prime}\right) \\
\end{array}$ & $\mathbf{T}^{\circ} \mathbf{C}^{\mathrm{a}} /$ Product (bp) & Reference \\
\hline stx 1 & $\begin{array}{l}\text { F- AAGTTGCAGCTCTCTTTGAATA } \\
\text { R- TGCAAACAAATTATCCCCTGAG }\end{array}$ & $50 / 364$ & 20 \\
\hline stx 2 & $\begin{array}{l}\text { F- GGGCAGTTATTTTGCTGTGGA } \\
\text { R- GTATCTGCCTGAAGCGTAA }\end{array}$ & $50 / 386$ & 20 \\
\hline elt I & $\begin{array}{l}\text { F- AGATATAATGATGGATATGTATC } \\
\text { R- TAACCCTCGAAATAAATCTC }\end{array}$ & $48 / 300$ & 21 \\
\hline ipaH & $\begin{array}{l}\text { F- GGTCCTTGACCGCCTTTCCGATACCGTC } \\
\text { R- GCCGGTCAGCCACCCTCTGAGAGTAC }\end{array}$ & $50 / 600$ & 22 \\
\hline Eae & $\begin{array}{l}\text { F- GACCCGGCACAAGCATAAGC } \\
\text { R- CCACCTGCAGCAACAAGAGG }\end{array}$ & $50 / 384$ & 23 \\
\hline$p C V D 432$ & $\begin{array}{l}\text { F- CTGGCGAAAGACTGTATCAT } \\
\text { R- CAATGTATAGAAATCCGCTGTT }\end{array}$ & $48 / 630$ & 24 \\
\hline est I & $\begin{array}{l}\text { F- ATTTTTATTTCTGTATTGTCTTT } \\
\text { R- GGATTACAACACAGTTCACAGCAGT }\end{array}$ & $48 / 176$ & 25 \\
\hline
\end{tabular}

Table 2. Frequency of pathotypes of Escherichia coli isolated from children at Campinas, Brazil (2006)

\begin{tabular}{|c|c|c|c|c|c|}
\hline & \multicolumn{2}{|c|}{ Autumn } & \multicolumn{2}{|c|}{ Winter } & \multirow[b]{2}{*}{$\begin{array}{c}\text { Number of positive } \\
\text { samples }(\mathrm{n}=\mathbf{1 8 8}) \\
(\%)\end{array}$} \\
\hline $\begin{array}{c}\text { Diarrheic } \\
\text { E. coli }\end{array}$ & $\begin{array}{l}\text { Fist set samples } \\
\qquad(\mathrm{n}=\mathbf{7 0})\end{array}$ & $\begin{array}{l}\text { Second set } \\
\text { samples } \\
(n=34)\end{array}$ & $\begin{array}{c}\text { Third set } \\
\text { samples } \\
(\mathrm{n}=50)\end{array}$ & $\begin{array}{c}\text { Fourth set } \\
\text { samples } \\
(\mathbf{n}=34)\end{array}$ & \\
\hline EAEC* & 8 & 2 & 2 & 3 & $15(7.9)$ \\
\hline EPEC & 6 & 4 & 7 & 2 & $19(10.1)$ \\
\hline ETEC & 0 & 1 & 0 & 0 & $1(0.5)$ \\
\hline STEC & 1 & 0 & 0 & 0 & $1(0.5)$ \\
\hline Total & 15 & 7 & 9 & 5 & $36(19.1)$ \\
\hline
\end{tabular}

Statistical analysis

The identification of different diarrheogenic $E$. coli groups was assessed by means of the Chi-square test (Fisher's exact test). Statistical significance was set at $p<0.05$.

\section{Results}

In the 188 stool samples analyzed, $36(19.1 \%)$ were PCR positive for at least one of the virulence factors associated with diarrheic E. coli (Table 2). Nineteen strains were positive for eae (EPEC) $(p>$ 0.05); 15 strains were positive for pCVD432 (EAEC) $(p>0.05)$; one strain was positive for $s t x 1 /$ stx 2 (STEC) $(p<0.05)$; and one strain was positive for eltI (ETEC) $(p<0.05)$. One sample was positive for both EPEC and EAEC (Table 2). Rotaviruses were not identified in this study. In the infantile population studied, diarrheic $E$. coli levels were not significantly high ( $p>0.05)$; however, the predominance of EPEC and EAEC in isolates from children is statistically significant.

\section{Discussion}

In developing countries, bacterial agents are the main cause of diarrhea in children whereas viral agents are more prominent in industrialized countries [14]. In day-care centres, the transmission of infection due to enteric pathogens and rotavirus is usually common among children with no evident signs and symptoms of gastroenteritis. However, many of these children may also have severe dehydration or be the source of exposure to their families [1]. Therefore, they act as silent carriers of infection and play an important role in the transmission of disease throughout the community.

It is important to check the presence of such pathogens in asymptomatic patients. In the present study, we analyzed 188 stool samples of children who attended a nursery in Brazil in a six-month period that included autumn and winter to verify if these children could be asymptomatic but still be rotavirus and E. coli carriers. Surprisingly, none of 
the samples was positive for rotavirus; however, $19.1 \%$ carried different pathotypes of diarrheic $E$. coli. EPEC was the most frequent category of diarrheic E. coli identified in children. Historically, EPEC has been considered a group that presents serotypes associated with infantile diarrhea [15]. This group can present both typical and atypical pathotypes. Atypical EPEC are strains with a diversity of genetic combinations involved with pathogenicity [7]. The role played by these EAF+ and EAF- strains outside the EPEC serogroups in endemic diarrhea has not been established. In industrialized countries, they have become a more frequent cause of diarrhea than typical EPEC, and the same shift may be occurring in Brazil [16]. Brazilian studies have shown identification of this group in samples of healthy and symptomatic children $[14,15]$ and EPEC are more commonly isolated in healthy children than from children with diarrhea [15]. In this study, we detected EPEC in the feces of healthy children who stay all day in a day-care center. This observation indicates that apparently healthy children can be a important source of infection.

Another group of diarrheic E. coli identified in this study was enteroaggregative $E$. coli (EAEC). The majority of studies involving the detection of EAEC have been based on a hybridization test using target sequences of adhesion genes. Although the sensitivity of this test has varied in population studies, it is very specific [17]. Recently, PCR assays that target genes located on the pAA, including aat, aap and aggR, have been described. However, EAEC are a heterogeneous group, and not all strains that adhere to HEp-2 cells in a stacked-brick formation harbor the pAA plasmid. Studies have shown that the aaiA and astA genes are potential targets for detecting both groups [18]. EAEC are detected in $7.9 \%$ of the cases, surpassed only by the EPEC group (10.1\%). Other studies in Brazil show that this category of diarrheic $E$. coli is frequently isolated from children with or without diarrhea [15].

Enterotoxigenic E. coli (ETEC) was detected in only one strain $(0.5 \%)$ in our study and these findings are not in agreement with those of another study in our country [17]; however, it is important to note that we analyzed healthy children. In this study, the ETEC detection rates were significantly lower than rates identified in other studies $[14,15,17]$. Enteroinvasive E. coli (EIEC) was also identified in only one strain. Cases of diarrhea by EIEC are endemic and sporadic [7]. In Brazil, EIEC could be isolated in children over two years of age when they present acute diarrhea [15]. In addition to the results mentioned above, we detected only one STEC strain, confirming previously published results which showed that STEC is not frequently identified in children with symptoms, but mainly in apparently healthy children [15].

In conclusion, these results show the potential of investigating endemic enteric pathogens in the community, because healthy individuals may have these pathogens as a member of their microbiota $[14,18,19]$. The occurrence of diarrheic $E$. coli in this population and possibly in children without subclinical rotavirus infection indicates that apparently healthy individuals can be sources of potential pathogens for diarrhea infection, representing a significant public health problem. These facts justify the development and implementation of rapid identification methods.

\section{Acknowledgements}

We are extremely grateful to Ana Silvia de Souza Lima Michelone, the nurse of the day-care center who supervised and organized the collection of stool samples. Also, we would like to thank to all the nurseries that helped with sample the collection, and the parents and children who participated in the study.

\section{References}

1. Nesti MMM and Goldbaum M (2007) Infectious diseases and daycare and preschool education. J Pediatr 83: 299-312.

2. Guerrant RL, Hughes JM, Lima NL, Crane J (1990) Diarrhoea in developed and developing countries: magnitude, special setting and etiologies. Rev Infect Dis 12: 41-51.

3. Parashar UD, Holman RC, Clarke MJ, Bresee JS, Glass RI (1998) Hospitalizations associated with rotavirus diarrhea in the United States, 1993 through 1995: surveillance based on the new ICD-9-CM rotavirus-specific diagnostic code. J Infect Dis 177:13-7.

4. Linhares AC (2000) Rotavirus infection in Brazil: epidemiology and challenges for its control. Cad Saúde Púb 16: 629-646.

5. Correia JB, Patel MM, Nakagomi O, Montenegro FM, Germano EM, Correia NB, Cuevas LE, Parashar UD, Cunliffe NA, Nakagomi T (2010) Effectiveness of monovalent rotavirus vaccine (Rotarix) against severe diarrhea caused by serotypically unrelated G2P[4] strains in Brazil. J Infect Dis 201: 363-369.

6. Souza EC, Martinez MB, Taddei CRT, Mukai LM, Gilio AEG, Racz MLR, Silva LS, Ejzenberg B, Okay Y (2002) Perfil etiológico das diarréias agudas de crianças atendidas em São Paulo. J Pediatr 78: 31-38.

7. Nataro JP and Kaper JB (1998) Diarrheagenic Escherichia coli. Clin Microbiol Rev 11: 142-201.

8. Okeke, IN (2009) Diarrheagenic Escherichia coli in subSaharan Africa: status, uncertainties and necessities. J Infect Dev Ctries 3: 817-842.

9. Law D and Chart H (1998) Enteroaggregative Escherichia coli. J Appl Microbiol 84: 685-697. 
10. Nishi J, Sheikh J, Mizuguchi K, Luisi B, Burland V, Boutin A, Rose DJ, Blattner FR, Nataro JP (2003) The export of coat protein from enteroaggregative Escherichia coli by a specific ATP-binding cassette transporter system. J Biol Chem 278: 45680-45689.

12. Estes MK and Cohen J (1989) Rotavirus gene structure and function. Microbiol Rev 53: 410-449.

11. Herring AJ, Inglis NF, Ojeh CK, Snodgrass DR, Menzies JD (1982) Rapid diagnosis of rotavirus infection by direct detection of viral nucleic acid in silver-stained polyacrylamide gels. J Clin Microbiol 16: 473-477.

12. Toledo MRF, Fontes CF, Trabulsi LR (1982) EPMModificação do meio Rugai e Araújo para realização simultânea dos testes de produção de gás a partir de glucose, $\mathrm{H}_{2} \mathrm{~S}$, urease e triptofano desaminase. Rev Microbiol 13: 309315.

13. Toledo MRF, Fontes CF, Trabulsi LR (1982b) Um meio para a realização dos testes de motilidade, indol e lisina descarboxilase. Rev Microbiol 13: 230-235.

14. Bueris V, Sircili MP, Taddei CR, dos Santos MF, Franzolin MR, Martinez MB, Ferrer SR, Barreto ML, Trabulsi LR (2007) Detection of diarrheagenic Escherichia coli from children with and without diarrhea in Salvador, Bahia, Brazil. Mem Inst Osw Cruz 102: 839-844.

15. Regua-Mangia AH, Gomes TA, Vieira MA, Andrade JR, Irino K, Teixeira LM (2004) Frequency and characteristics of diarrhoeagenic Escherichia coli strains isolated from children with and without diarrhea in Rio de Janeiro, Brazil. J Infect 48: 161-167.

16. Trabulsi LR, Keller R, Gomes TAT (2002) Typical and Atypical Enteropathogenic Escherichia coli. Emerg Infect Dis 8: 508-513.

17. Gomes TAT, Blake PA, Trabulsi LR (1998) Prevalence of Escherichia coli strains with localized, diffuse and aggregative adherence to HeLa cells in infants with diarrhea and matched controls. J Clin Microbiol 27: 266-269.

18. Jenkins C, Tembo M, Chart H, Cheasty T, Willshaw GA, Phillips AD, Tompkins D, Smith H (2006) Detection of enteroaggregative Escherichia coli in faecal samples from patients in the community with diarrhoea. J Med Microbiol 55: 1493-1497.

17. Guth BE (2000) Enterotoxigenic Escherichia coli-an overview. Mem Inst Osw Cruz 1: 95-97.

18. Scaletsky ICA, Fabbricotti SH, Carvalho RLB, Nunes CR, Maranhão HS, Morais M B, Fagundes-Neto U (2002)
Diffusely adherent Escherichia coli as a cause of acute diarrhea in young children in northeast Brazil: a case-control study. J Clin Microbiol 40: 645-648.

19. Vilchez S, Reyes D, Paniagua M, Bucardo F, Mollby R, Weintraub A (2009) Prevalence of diarrhoeagenic Escherichia coli in children from Leon, Nicaragua. J Med Microbiol 58: 630-637.

20. Ojeniyi B, Ahrens P, Meyling A (1994) Detection of fimbrial and toxin genes in Escherichia coli and their prevalence with piglets with diarrhea: The application of colony hibridization assay polymerase chain reaction and phenotype assays. J Vet Med 41: 49-59.

21. Schultsz C, Pool GJ, Van Ketel R (1994) Detection of enterotoxigenic Escherichia coli in stool samples by using nonradioactively labeled oligonucleotide DNA probes and PCR. J Clin Microbiol 32: 2393-2397.

22. Sethabutr O, Venkatesan M, Murphy GS, Eampokalap B, Hoge CW, Echeverria P (1993) Detection of Shigella and enteroinvasive Escherichia coli by amplification of the invasion plasmid antigen $\mathrm{H}$ DNA sequence in patients with dysentery. J Infect Dis 167: 458-461.

23. Yu J, Kaper JB (1992) Cloning and characterization of the eae gene of enterohaemorragic Escherichia coli O157:H7. Mol Microbiol 6: 411-417.

24. Schmidt H, Knop C, Franke S, Aleksic S, Heesemann J, Karch H (1995) Development of PCR for screening of enteroaggregative Escherichia coli. J Clin Microbiol 33:701--705.

25. So M, McCarty BJ (1980) Nucleotide sequence of the bacterial transposon Tn1681 encoding a heat-stable (ST) toxin and its identification in enterotoxigenic Escherichia coli strains. Proc Nat Acad Sci 77: 4011-4015.

\section{Corresponding author}

Cláudia de Moura

Department of Genetic, Evolution and Bioagents, Institute of Biology, CP 6109, State University of Campinas - UNICAMP, Monteiro Lobato, 13083-862, Campinas, SP, Brazil.

E-mail: cmoura.bio@gmail.com

Fone: $(+5519)$ 3521-6272

Fone/Fax: (+5519) 3521-4884

Conflict of interests: No conflict of interests is declared. 